\title{
Plant designs in Sassanid Period moldings
}

\author{
Somaye KHAZAEIMASK ${ }^{1}$, Moeine Sadat HeJAZI ${ }^{2}$ \\ ${ }^{1}$ Department of Visual Communication, Faculty of Art, university of Bojnord, Bojnord, lran \\ s.khazaeimask@gmail.com \\ ${ }^{2}$ Department of Traditional Art and Craft, Faculty of Art, university of Bojnord, Bojnord, lran \\ M.Hejazi@ub.ac.ir
}

\begin{abstract}
Sassanid Dynasty art is considered as digest of all Iran ages art. The most characteristic of Sassanid art is its decorative designs and one appearance of the design is in the period moldings that has flourished in the period. Molding is more specific and more advanced from the application point and work model among different Sassanid arts. Sassanid molding designs explain the effects that the art has had later on works of Islam early ages, using of changes and transformations especially to Islamic art periods in most architecture, metal work and textiles production works. The project aimed to study plant designs and its usages in Sassanid art, and emphasizes on moldings on structures. The questions that answered by the project are: what are the used concepts in plant designs? What was the aim of the designs usage in decorations? According to results obtained among Sassanid molding designs, plant designs allocated most part of decoration to themselves. Moreover the beauty aspect, most of the designs had been as a symbol and had special concepts. And Sassanid artist has noticed to nature, very much. The project has studied designs in Sassanid moldings based on library studies and by descriptive- analytic method.
\end{abstract}

Keywords: molding, plant designs, Sassanid.

\section{Introduction}

The most prominent ethnic and indigenous characteristics of a nation is relying on achievements that mentioned as art, in human and social culture that is peak of a valuable self-graph of the nation inner feeling and emotions that included different and diverse majors based on their desires and intentions of different generations continuity. Sassanid art included extensive territory from Far East to Atlantic coasts and had insignificant role in formation of European and Asia art (Bousali, 104:1376).

Plasterwork and molding in Sassanid dynasty had important position in decorative arts and considered as cover for brick walls and walls constructed by cobble stone. Moreover many format and wood carved stokes were built and used in government buildings. Plasterwork and plaster usage has long history in Iran, for example oldest plaster work that has obtained in recent researches in Khuzestan (Ansari, 319:1365).

The project purpose is survey the Sassanid moldings with emphasis on plant designs. Interested questions in the project are: how the designs are important in Sassanid art? What are the latent concepts in the molding?

Many studies have done about Sassanid moldings and even some of them used in the project. But the project studied plant designs and its concepts carefully and extensively. 


\subsection{Molding}

Sassanid moldings works show the fact artists of the technique desire to reveal works parallel with great bases of Achaemenian and masterpieces of their covenant about molding, and in the way innovated basic methods and diverse designs of molding through much effort so that created in Ctesiphon ( Sassanid palace) 8 types, and in Kish Palace, 40 different types. The extension of diversity in schemes and designs show imagination of

Artists who had tried to show molding designs, better and beautiful, they compassed perfection way more fruitful than before period (Ansari, 325:1365).

It has met with usage and establishment of molding using more extensive insight and more developed principles than ancestors. It also diversity using other arts of the period caused to extend the method and presentation of better and more valuable schemes and also usage of more pleasant colors that play main role in decorations of architecture spaces, designs and chalky objects in Sassanid dynasty, made more flourished molding art imprinting in the period (Haman, 326).

Artists in Sassanid dynasty try to extend forms by eastern theme and decoration be appeared with their nature mode. It means that if it interested branch and leaf of tree or human and animal design, it appeared in its same realistic combination, therefore schemes and main painting divided to plant, human and animal groups that show molding art in Sassanid dynasty (Ansari, 322:1365).

Primary decorations were done on earthenware and when paid attention more to architecture, elements and designs represented and were used in buildings. firstly the created decorations were primary and very simple schemes, but with increasing of decorative elements and designs on high relief, it also used other artistic works and the abundance caused to divide the designs to three decorative groups in geometric, plant and human designs on works (Haman, 321).some works and valuable buildings that established in Sassanid dynasty, have most beautiful molding decorations that here we explain some parts of them moreover the decorative designs and factors. Some chalky decorations are additional, means they gave decorative aspect to work with addition, connection and installation, without be used in building or structure (Ansari, 340:1365).

\subsection{Classify the decorative paintings in Sassanid molding}

Study the valuable molding remainders and works allows to explore valuable cases of molding designs in the period that unconsciously has effected on designs supplement of carpet, metal ware, sculpture and decorative forms of high relief whether inside and outside of Iran. Due to designs extensity, they should divided to four distinct groups included 1-geometric designs 2-plant designs 3animal and human designs 4-role of line and inscription on chalky works (Ansari, 326:1365). The being studied topic is plant design.

\section{Plant paintings}

It seen in some molding remainder works that most parts of them included plant schemes so that have graced the works in special limit. Geometric designs replaced with plant ones but with some change and usage of sterilized schemes which are unique and included molding schemes, in plant combinational forms. It seen in middle part of the components, a branch of leaf like to cypress or plantain that represent combination of five Palmet leaves which themselves have five leaves in every side. Most important plant designs that seen in molding works of Sassanid are the following shapes: 
Palmet, vine and ivy design, lilies, grape fruit, Acantous, lotus and rosette flower design, oak design and designs like as leaf and acanthus (Ansari, 328:1365).

\subsection{Palmet}

It is a kind of plant that it's different kinds seen on earthenware designs, through history periods and even before history. The plant form is holy in religious motifs and used as presage and blessing. As rosette or lilies and tree twig pomegranates there were always in high relief of achaemenid, they seen in the period works. Palmet design seen in Kish and Ctesiphon palaces works and in Elamite civilization of Shush and Mesopotamia works, and also presented in form of palm tree clearly in Ashouri and Sumerian high relief. Later, Palmet design completed and converted to arabesque form and entered to carpet and tile designs (Ansari, 328: 1365) (figure 3).

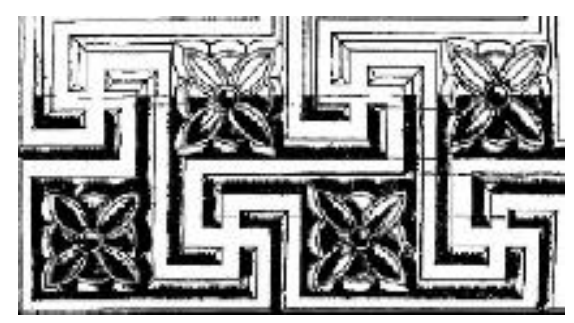

Figure 1: Inside decorations of Kish raised molding arch, palace 1 (pup, 766: 1387).

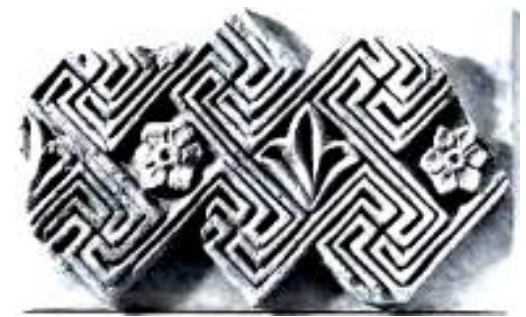

Figure 2: A part of Ctesiphon palace molding body, (Baltroshaits, 84:1384).
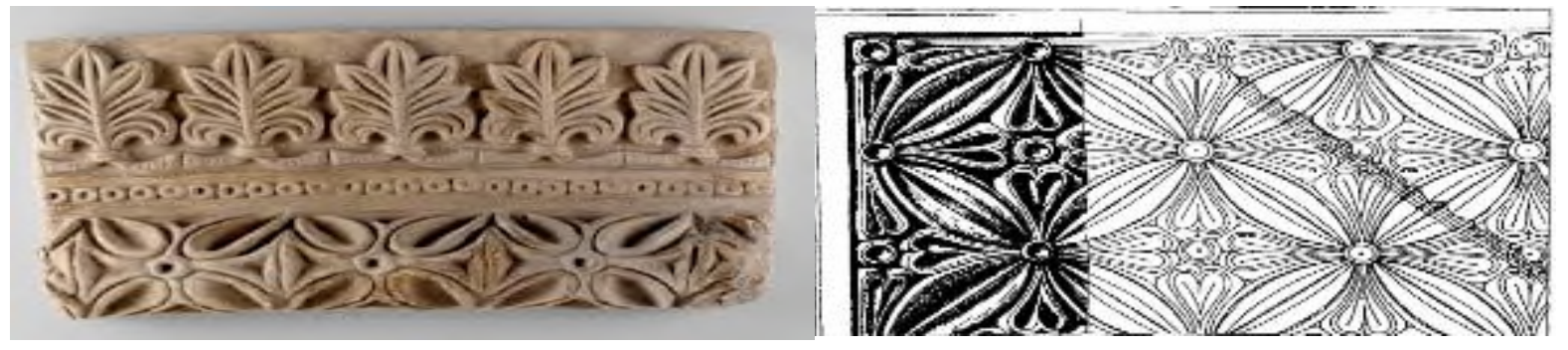

Figure 3: Right side, body cover, Kish molding palace 1 (pup, 767:1387). Left side, a part of Matigh arch, state museum of Berlin (Baltroshaits, 82:1384). 


\subsection{Lotus and Acountos flowers}

Acountos is a leaf like to acanthus or grapevine and nearly is close to Palmet leaves in form, but its leaves are wider. Lotus flower is unique designs in Achaemenid high relief and employed in margins of bases. The flower seen in different measures and diverse shapes in components of obtained moldings in Chal Tarkhan that there is now in Ancient Persia museum. Lilies has unique beauty that seen as a symbol in artists' works (Ansari, 329:1365).

\subsection{Vine and Ivy design}

The kind of design had been used in Mesopotamia designs, and in Iran grape design seen in moldings related to Chal Tarkhan Palace and in a part of molding works of Kish palace that now maintained in Ancient Persia museum. Gradually along with changing the molding art in Sassanid dynasty, also paintings burgeoned. A bird as eagle or Quebec seen on Chal Tarkhan molding and seen flower, bush and pomegranate designs around it. In some molding works, pomegranate leaf design located on concentric shoot that see its phases from bud to flower and fruit and sometimes in stylized designs. Later the mentioned design employed in drawing on carpet and rug (figure 4) (Ansari, 330:1365).

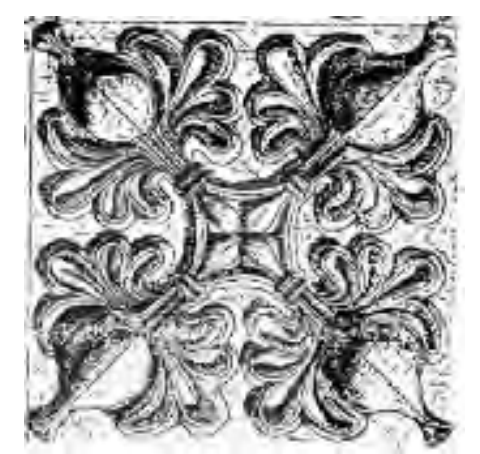

Figure 4: Pomegranate leaf design that located on concentric shoot and the design appeared as stylized form, raised molding from Kish palace 1 (Pup, 773:1387).

\subsection{Oak design}

Oak is an old tree of Iran that its fruit has been used and its design inspired by artists to decorate the moldings.it can find by studying of plant designs in molding works that generally plant designs have divers shapes and are partially imaginary and especially curvature of leaves such as leaf of fig, grape, palm, acanthus, lilies and geometric designs are common and artists could established valuable phenomenon by combining them that later have been used in etching on carpet, mosaic, tile and in drawing (figure 5) (Ansari, 328-333:1365).

Plant paintings include two groups: a group is free exhibition of leaves and stems with real animation, and other are inanimate and summarized designs that follow the geometrical rules completely. Some designs of the first group are: vine leaves has drawn a long with an Afryz and connected together by good looking arches (Baltroshaits, 19: 1384). 
Compound of asymmetric leaves cluster repeat implemented in Ctesiphon (figure 6), and a few branch with fruit and leaf implemented in Kish that also seen in Silvery and golden objects and in fact make an egg unit (pup, 766: 1387).

Arrangement of palm leaf has many diversity that a kind of its seen as egg unit in decorative moldings. Some of them designed on Lotuse blossom that show three petals (figure 7, right) and other form includes five, six, seven or eight blades around central blade ( figure 7, middle) and sometimes bottom blades became to scroll (figure 7, left side) base of the designs founded on vin leaf model or acanthaceous leaf arrangement.

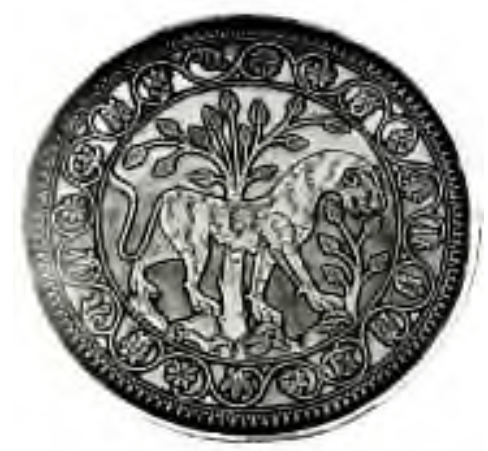

Figure 5: Decorative designs such as lion, life tree and also plant designs such as rosette, Palmet, acanthus leaf and Lotuse flower seen in the picture that included decorations of Sassanid silver plate (pup, 1387).

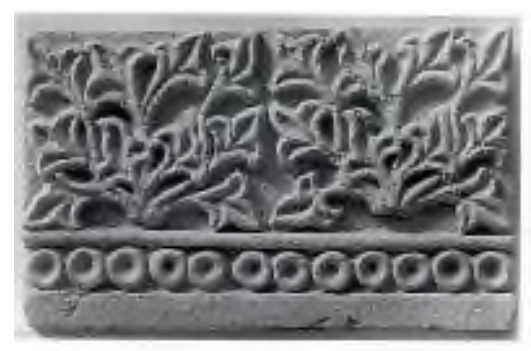

Figure 6: Molding decorative component, Sassanid Ctesiphon palace (Baltroshaits, 83:1384).
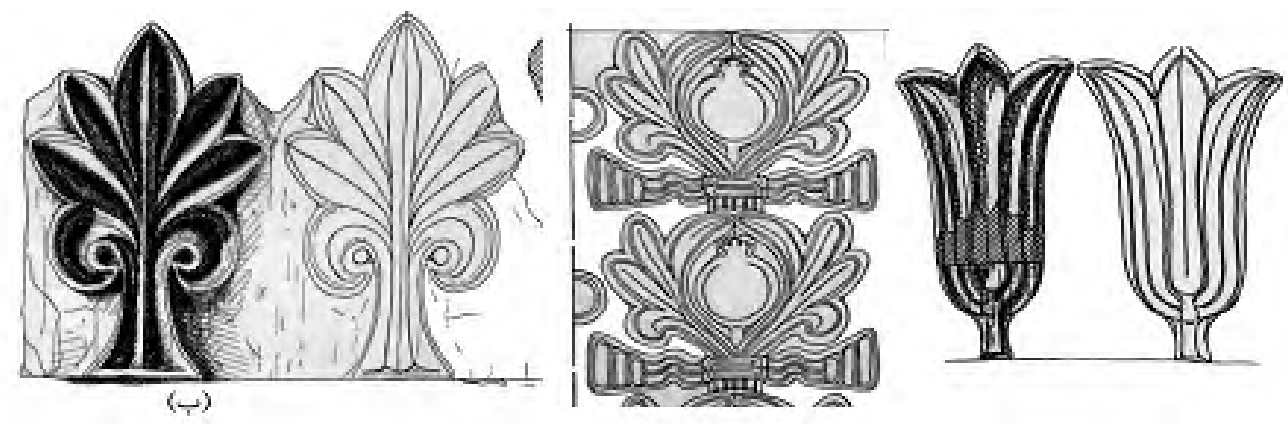

Figure 7: Left side, Afryze, Kish palace 2 of, middle of body cover, Kish Palace 1, right side, Afryze, molding designs of Kish, palace 2 (pup).

Other decoration is conventional design of a high palm branch with about 20 stem leaves in every side. In another case, arrangement of two half balm leaf, surrounds bunches of leaves closed often by special strip of Sassanid head hair. Sometimes plant painting combined with Sassanid symmetrical wings that showing the eagle. 
Different forms there are about this that their design has been enriched by making diversity in relation and combination (Baltroshaits, 19: 1384). Another case of plant decoration is the rows of obvolute leaves, suffocating of Teheston shawl in Kish and Ctesiphon buildings are located putting on each other (like as fish scale) (Baltroshaits, 20: 1384).in a kind of arrangement of palm leaf with three leaves that cover the wall completely, every decorative unit is in form of wood carved diamond. Vertical axis of middle blade and lateral sidling blades fill two sides of the space (figure 8).

More enriched designs of palm leaf arrangement included three, five or seven leaflets with ordered distances employed to making space for Afryzes and Gharnizes (figure 9, rightside). Sometimes the designs are single and in some cases alternate with smaller palm leaf or several blades flowers (figure 9) that connected to each other by usual stem. There is an outstanding example of the design in Ctesiphon where half acanthus leaves located a few sidle on continuous stem (Baltroshaits, 21: 1384).

Different four blades palm leaf arrangement seen on several Kish decorative framings (figures 4, 10). Between of the four blades flowers of palm leaf filled by painting of combining with round framings (figure 10). The interesting point in designs is that the setting of palm leaf arrangement on square diameters is actioned so that make a quaternary group in center (figure 10) (Baltroshaits, 21:1384).

Palm leaf arrangement with three blades seen as smaller scale of the design, and other measures have seven leaflets. When seeing decoration of a wall, we see that larger four blades leaves in arrangement settle on vertical and horizontal axis of a square series, surround smaller design and considered as controller frame for them. Another kind of arrangement is actioned placing of egg design in a circle and making a star. It seen a multi blades flower consists of six palm leaf arrangements that radiated from common stem by design method in Ctesiphon building. In more detail decoration than Ctesiphon, it implemented actioned design with circle framing, alternately placing of three leaves palm leaf arrangement (shaped lilies) on main axis with pomegranate flowers on tended axis (figure $10 \mathrm{~b}$ ).

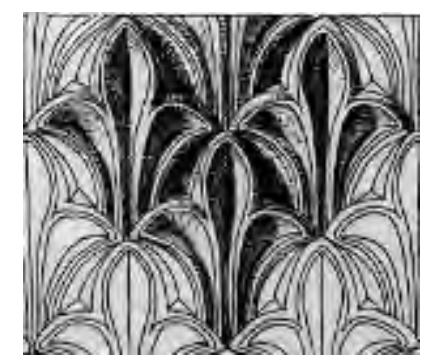

Figure 8: Molding high relief, Kish, palace 1. 

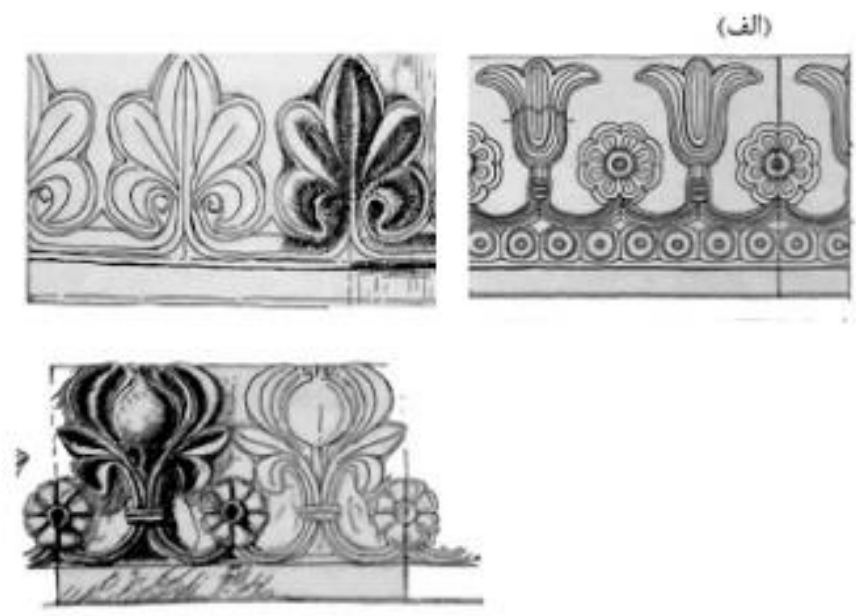

Figure 9: High reliefs of Kish moldings, palace 1, Afryzes and there is frame aside them (Baltroshaits, 23: 1384).

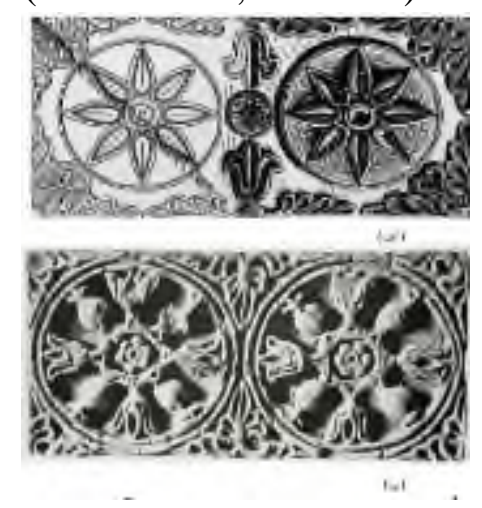

Figure 10: A: body cover, Kish molding high relief, palace 1. B: Ctesiphon molding decorative component, Sassanid dynasty, a part of body, governmental museum of Berlin (pup).

Their stems are squares that an octagonal star created by their interference. Special group of models composed from curved stems bearer the leaf and has very elegant and mixed geometry. The simplest case of the kind of arrangement twisty stem bears alternately leaf and fruit like a bunch of grapes that fill interior section of stem curvature (figure 12).

Half acanthaceous leaf arrangement and its stem became to a kind of stem and leaf scroll arrangement on several beautiful Afryzes in Kish and Ctesiphon (figure 13). The painting that afterward named painting 1 (figure 33, A) that compos the extensive spectrum base of sidling designs kinds (Baltroshaits, 24: 1384).

Stems are single on molding Afryz in Ctesiphon. Twists are reverse and returned to leaves of half acanthaceous leaf arrangement with curved leaf veins that emphasis on twist movement of stem. A single vein leaf located on right stem between two acanthaceous leaf arrangement and also it seen a single vein leaf alternately with the main unit (three sections). In another study about analyze the three sections unit, central leaf is single and turning that arrange corners of a decorative tablet (figure 14, A). In this regard but in another different picture, molding tree in Ctesiphon consists twisted stems that surrounded by pomegranate, in palm leaf arrangement it is interesting that two pairs of birds in the top and male peacock in bottom are symmetry and a front of each other (figure 14, B) (26-27:1384).

Twofold painting stems connected together reversely and there is a half acanthus leaf its inside. Then the two half leaves connected to each other and mixed in a cut palm leaf. It has implanted 
analysis design in independent units, in first case. In Taq- e Bostan' design has a continuous structure. Two stems that make frame, connected to gather by palm leaf. Palm leaf is independent motif of form and attribute.

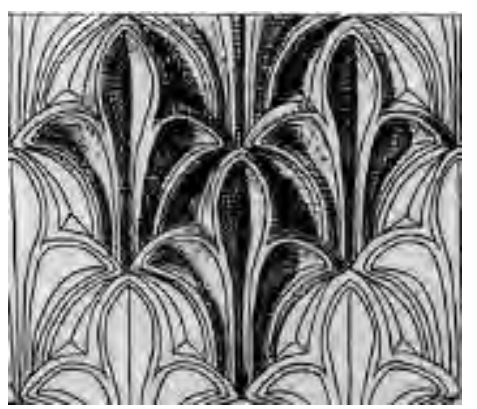

Figure 11: Body cover, molding high relief, Kish, palace 1 (pup, 774: 1384).
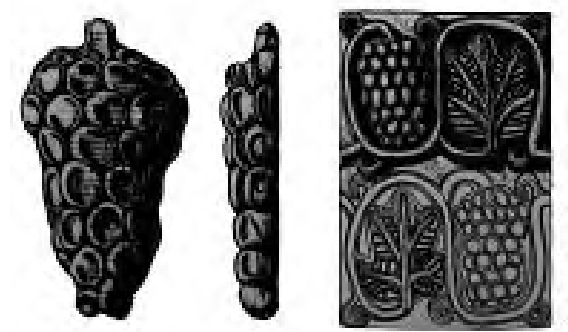

Figure 12: Molding high relief of Sassanid dynasty, Kish (pup, 775:1387).

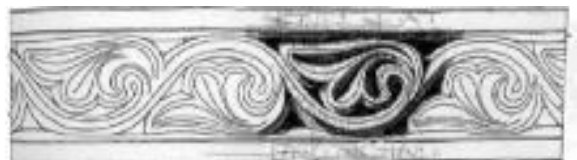

Figure 13: Molding high relief, Kish, palace 1 (pup, 1387).

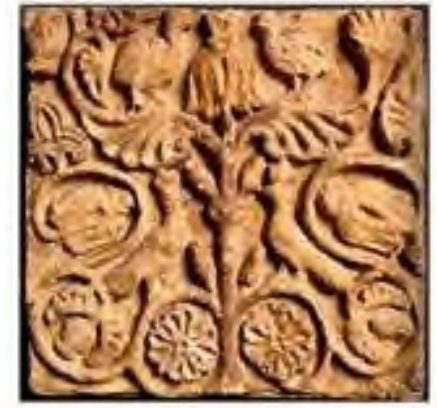

A

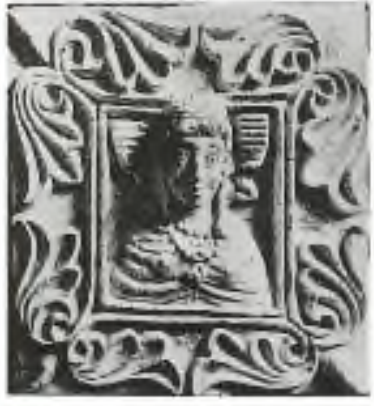

B

Figure 14: A, framing from Damghan, Pennsylvania art museum, B: a part of body cover, Ctesiphon, molding, Sassanid dynasty (pup, Wikimedia. Org).

The design has come on pilaster of old castle (figure 15, B) in several rows on each other. An amazing change in tissue design seen in molding cover of Ctesiphon (figure 16). In the case instead of palm leaf, it has come a triple oak cluster inside of a circle stem and its inside filled by triple small 
leaflets. The set mashed in horizontal- vertical rows and alternated horizontally in revers form that has given to the design a skeleton of a comprehensive continuous wavy stem (Haman, 774).

In Afryz design of Kish and Ctesiphon, there is a distance between reverse heart and sharp leaf. In continuous complex changes, fanwise leaves drawn on painting that creates a new structure (figure 18) (Haman, 776).

Mainly function of Sassanid dynasty decorations, similar shapes repeat and change their relation with each other create many groups of models. Thus cross broken Chalipa created by Khampa chain, circles interference creates multi blades flowers. Four blades flowers made by palm leaf arrangements located on square Qatar and the actioned flowers create multi blades flowers. A complete set of reverse heart shaped paintings or split palm leaf arrangement created through diverse connections of volute arrangement of branch, leaf and twist stems.

When it recognized nature of main painting and determined design function, even a very complex structure can be separated to its components and it can be determined the formation method.

The advancements are not only result of auto building or inscriptive innovations expression. Sassanid artists rather founded measured geometrical structure that is regular of determination line path in every point and of curve move by helping of a mathematical type. Being random of the design is irrational. When studying the design through separation, probably lt's ambiguous complexity reduces to only one shape, line or curvature. Thus main painting nature can be recognized although it implanted by different rules. Although the compound system may seems similar and integrated, they have complex base; apparently it has different inspiration sources and different factors. Abstractionoriented idea of ancient Asia appears here again. Yet some special rules of intact Greek art transformed to the art. Finally spontaneous creative experiences created in the period (Baltroshaits, 29-31:1384).
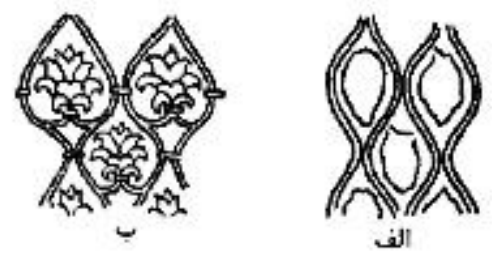

Figure 15: A: a ring of third millennium B.C urea. B: Pilaster belong to old castle (pup, 776: 1387).

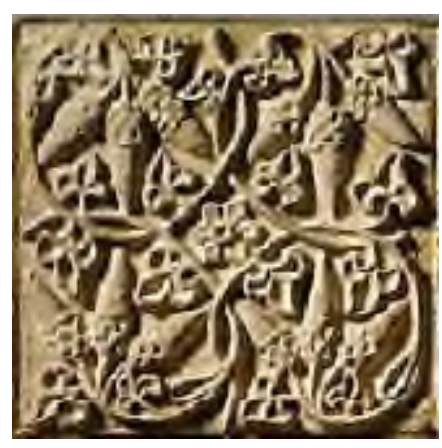

Figure 16: A part of molding Ctesiphon (84: 1384). 


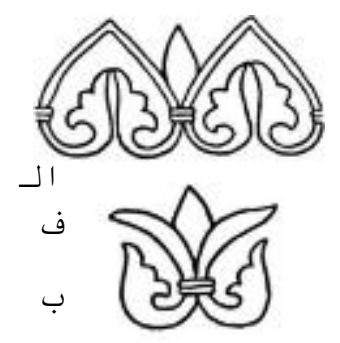

Figure 17: A: Repeat, separation and conversion (pup, 776:1387).

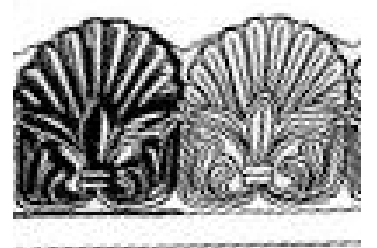

Figure 18: Tthe form of free arch or Gharniz, high relief of Kish palace 2(pup, 778: 1387).

\subsection{Paintings base}

Flower shaped paintings that had used in Lurestan bronzes have extended mostly in Asia. Its continuous can be followed during different civilization era that has had top share in achaemenid art (figure 19). It above stairs of Persepolis, enriches to column headings volute and decorates the cloths of shush archers. Although it implanted the design completely with natural and lively work that seems as a bunch of flowers, occasionally has maintained peripheral linear order.in Kish high reliefs. Petals that went out of two concentric circles, located in a circle, they have closest structure to jewels of Ure queen with a difference that they only magnified to implement on wall. Their work is a little enricher in Ctesiphon (pup, 779-780: 1387).

History of Sassanid plant designs is very complex. These decorations developed in two single routes with different origins that often should considered separately. On the one hand there are special single paintings, different shapes of leaves and palm leaf arrangement with distinct peripheral lines, on the other hand it can reached new paintings by masterly making regulations in order to extend and make different combinations by decorative geometry, which need to use the rules such as adaptation, symmetry, interference and change of axis (Baltroshaits, 36: 1384).

Multi blades flowers such as Khampa chain of Greek- Rome works may be extended to other places, but the designs there were in most decorations Mesopotamia and ancient Persia and Sassanid artists turned them in their same shapes and implanted them. The created four blades from division of interference circles arches usually seen on ancient Sumerian cylinders (Baltroshaits, 33: 1384).

The number of paintings such as acanthaceous leaf arrangement in Taq e Bostan, stem and leaf volute arrangement in the period maintained Greek nature without any change. Approximately it may the form of making leaf be more and its drawing be harder and while the lines are more regular, Rome-Greek imagination is very prominent. Conversely some kinds of palm leaf arrangement have completely different history; in leafy cases, it seen attitude to Asian old shapes (Baltroshaits, 37:1384). Greek0 Rome background is prominent in Kish and Ctesiphon works, especially on gates covered with leaf in the palaces. Because they were adapted directly from Helenian gates such as Miltus Gate and some examples of Roman flower garlands. On other hand, some palm leaves have another history; leafy cases like to Asian ancient shapes. Although it seems that high reliefs of grape leaf and bunch of grapes in Kish palace and some components in hall of Pennsylvania museum 
originate from Bacteria (Balkh) culture, but it is not close to carving of Nineveh branch and leaves. Nineveh instance implemented uniformly and arid, while Seyda case has enough depth and induces penumbra well. This point works about drawn palms leaves. Because is very similar to Ashoori linear method, and conversely go away from Helenian three dimensional method (pup, 780-781: 1387). Every possible sources of different palm leaf arrangements show that Sassanid Designers trended to early Asian cases instead of establish the Roman- Greek models. Even most adapted concepts from Greek sources ultimately originate from eastern sources (Baltroshaits, 39: 1384).

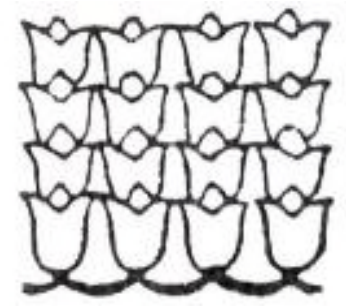

Figure 19: From Achaemenes palace, shush (pup, 872: 1387).

In the most of Sassanid palm leaves even if the design adapted directly from Greek, but it is prominent returning to special distinctive motifs of Asia (figure 21, s). Determination of five blades or seven blades palms leaf origination inside of civet base is difficult as Afryzes of Kish and Ctesiphon. Probably it adapted from Roman memorial stone arrays (figure 2, p) and or from old cases such as memorial stone of Hetti, especially found case in Tale Halph and Sakche Gazi (figure 21, A) and from Ashoori high reliefs. The paintings transferred from such Asian sources to Greek. A good intermediate example to the transmission is life tree (holy tree) design on Cretan pottery (figure 21, B). Other case of Kish palm leaf (figure 22, p) is three blades palm leaf with heavy line around it that is similar to lilies bud and apparently has local back ground. Their structure is completely clear on life tree shape and cylindrical stamps of Shush (figure 22, A) and has been used as lilies on Sassanid stamps (pup, p 998, 1387). Certainly symbolic importance of strips to fasten leaves and some palms leaf in Kish and Ctesiphon works is from Asian derivations and decoratively has similar purpose to Khers Abad' brick works purpose (in eastern north of Moosel in Iraq ) and has maintained the same view in their composition (pup, 781: 1387).

Palm leaf with symmetric wings is from eastern motifs, because from long ago, plants, animals and human factors mixed together in Asian art and the special wing shape certainly had related with wings of sun (figure 23) and show the eagle that had been the symbol of sun. Finally, some Sassanid art palm leaf such as palm leaf of old castle column headings that decorated by bunches of sharp leaves and thin curves that is certainly Ashoori (Hama, 781).

Studying the possible origin of Sassanid palms leaf main group, shows that Sassanid designers trended more to return to pervious Asian cases and avoided from Roman- Greek formats repeat, so that has borrowed cases from Helenian art that itself originated from east. Rules collection that determined the motifs' distribution and regulation, certainly had been established based on local traditions during the years, for example it can be named palm leaf case of Taqe Bostan. In the case, palms leaves placed on each other on vertical stem such as tree's (figure 24). Illustration concept and decorative structure of it return to pervious cases of ancient east. In art of western Asia, tree taken different shapes to itself as a ritual object, and the special method in placing palms leaves on vertical stem is a strategy that followed previously in achaemenid works in Shush and Persepolis and its roots was Ashoori, for example it seen in Nimrod (in south of Moosel in Iraq ) (pup, 782: 1387). 


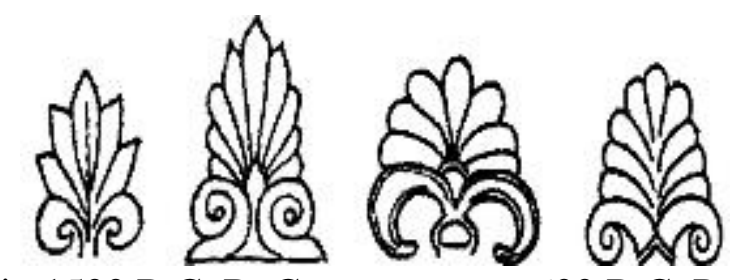

Figure 20: A: Sakche Gazi , 1500 B.C, B: Craten pottery, 600 B.C, P:Greek tomb stone, 400 B.C, S: Bani Hemad, 1100 A.C ( Baltroshaits, 38: 1384).

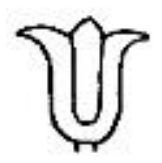

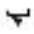

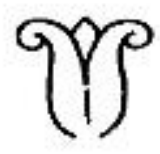

$+$

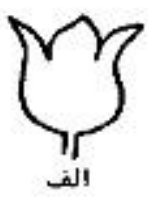

الف

Figure 21: A: From a stamp in Shush, 3000 A.C, and B: Hetti, 1500 A.C, P: Kish (pup, 781: 1387).

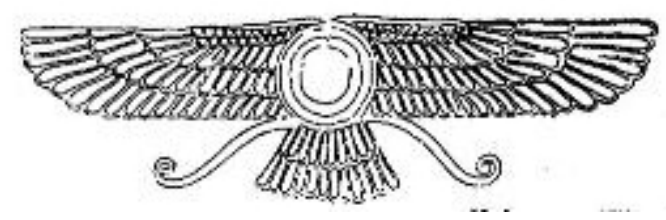

Figure 22: Semil Ghrohar, framer of glazed earthen high relief, Achaemenid palace

(Baltroshaits, 39: 1384).

Rotation of palm leaf arrangement with used multi blades flowers also observed in Kish and Ctesiphon. Wall cross model in Kish consists of consecutive rows of palm leaf arrangement with leaflets on slide vertical axis directly returns to achaemenid dynasty decorations, especially significantly on second Ardeshir palace stairs (383-379 B.C) in Shush( figure 20). The model is also concluded from Ashoori. Asian base of the model, means models rotation in paginated rows, to cover a surface has arrangement nature of eastern insight (Baltroshaits, 40: 1384).

It cannot recognized easily, origin of some regulations particularly cruciform regulation rule of palms leaves, because the method has been observed in many decorative collections and the claim of being Asian its origin is conservative, unless it be related with Sassanid art and shows its native attribute of design and implement by another attribute, and show. For example it can be referred to compound of palm stem and leaf that combining method of wavy stems and leaves collection that has created different designs in Sassanid art, originally had been Asian ancient art. Their main components place aside each other so show their origin way in cylindrical stamp of Klerk private set (figure 25, A). In the case, several designs of curve lines such as painting 1 gathered around an axis and created painting 2. Split Palm leaf implemented in painting 3 (pup, 782: 1387).

Composition in Sassanid decorative art has different attribute. Composition method of curves is more free and designer makes paintings again. Every paintings 1,2 and 3 can be analyzed and its main structure can be reached that concluded from each other respectively. The shapes are complicating, never lose their unity and appear on old stems of new leaves that have been adapted from different sources such as Ashoori palms leaves, blue lilies and Greek palms leave. But hand work collection of expert master is so assimilate that any shape itself has clear portion in organic composition (Haman, 783). 


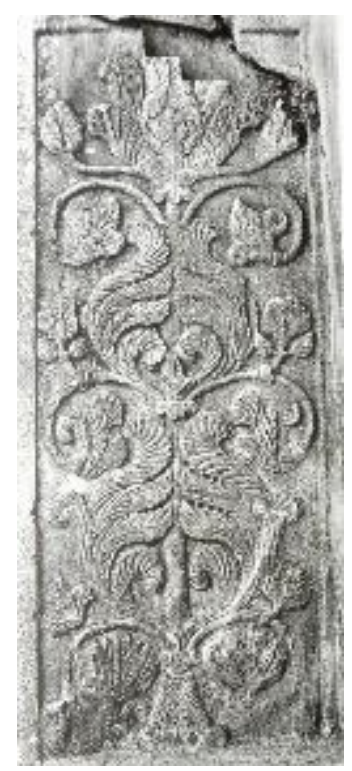

Figure 23: A tree aside Ivan arch, Bostan arch (Baltroshaits, 85: 1384).
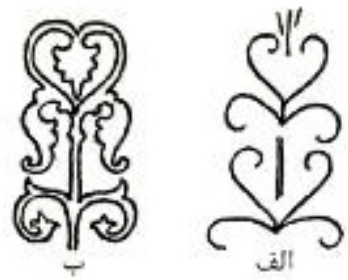

Figure 24: A: Cylindrical stamp, third thousand A.C, B: From Ghiravan, Hejri third century B.C (Baltroshaits, 40: 1384).

Thus Sassanid decorative art components and phases of extension principle included: the art appeared in period of history when Helenian world stood against of Asian forces who raised again, and reflected all resulted complications from it. Roman- Greek art not only transferred its paintings (that originated from Greek and Rome cultures) to Sassanid art, but itself was formed based on remains of east ancient civilizations that returned to them occasionally. Therefore guarded from all eastern main shapes that maintained in decorations means most conservative branch of creative art, and Sassanid artists who were loyal to their Asian roots, found their needs among the Asian shapes which mixed with new paintings. He tried to gain his hereditary right again, while Greek decorations were complex. They renewed eastern shapes and mixed them with complex curve lines and abstract taste and returned importance and main attribute to their design (pup, 783: 1387).

However if some factors were transferred through Greek art, certainly some others taken directly from ancient east. Firstly some insights were borrowed from achaemenid art which itself has Ashoori background and some others employed in Lorestan' bronzes. Secondly, carved paintings on metals and stamps continuously repeated for hundred years. And finally, it should referred to elements which maintained in buildings of Sassanid territory. Therefore it should be mentioned that nearly all Sassanid designs collections has belonged to Asian civilizations in spite of their different roots, and this point caused to unity of its style and competed with Roman-Greek art. contrary, exact high reliefs of acanthus leaf and plant rings with heavy fruits replaced with others factors such as technical skill, instead of penumbra ambiguous movements and visual masses flashiness, and although design of its structure is a little uniform and arid but has a usual system ( Haman, 784).

Decorative moldings follow geometrical rules to communicate rationally with building itself, because they designed to cover the building. Clearly many effort has done to coordinate architecture 
and decorations in Kish and Ctesiphon. Place of motifs and playing with them conform to architecture rules. For example, in twisted column headings, a measured system established between volute designs and motifs with carving of column headings structures. Shrewdly composition of stem and leaves, reinforces and highlights main sections, and decorations lines show move route of pressure and sliding. Apparently, other designs distribution follows the principles. Twisted leaves and branch chain that covers tablets and aspers, made valuable the building partially, because it implemented in common square units. Some four blades clovers and palms leaves located obliquely inside a rectangular frame, because it coordinates with carpets. Noticeably, it even faces design that any way has Helenian attribute, adapts to building architecture context (pup, 785-786: 1387).

Sassanid architecture decorations regulated based on concept and content, and designed to be installed in special place, contrary to Ashoori high reliefs which like as roll of fabric covered walls without minor relation to architecture context, it also contrary to Helenian high reliefs which exceed from themselves context. Decoration of Sassanid architecture in Kish, Ctesiphon and Damghan shows development of pervious diverse streams, presents general structure of designs chain, provides deterministic solution for the problems remained dissolved until that time, and completes the cycle that provides base of future changes (Haman, 785-786).

Sassanid paintings which had established based on eastern and Helenian cultures established a long with materials of other countries artists and gradually took to itself eastern color. At first they worked based on a single design but as progressing every one gained special own attributes (pup, 787: 1387).

Sassanid decorative method created in the land which has involved in its appearance more than other areas and has important place in history in spite of some limits. In the artistic works group which relates Greek and Rome world to Middle Ages rising, Sassanid art collected the most complete method especially most decorative of elements outlooks, and provided base of Mediterranean decorative arts extension (pup, 788: 1387).

\section{Conclusion}

Plant designs has allocated most shares in decorations, according to obtained results of Sassanid molding designs. Sassanid molding designs show creative mind of Iranian artists and most of the designs were as a symbol moreover the beauty aspect, showing that Sassanid artist noticed significantly to nature. For example Palmet plant which observed in molding designs of Ctesiphon palace, has had holy aspect and was noticed in religious ceremony and is sign of luck and blessing. Main attribute of Sassanid molding designs is designs rotation and the designs form base of Islamic designs. Studying of Sassanid dynasty art, shows partially relation of Iranian art to art of other countries and that how the connection caused to extend Iran artistic space gradually and continues for centuries, and today you see the effects on remaining works in inside and outside of our country borders. The designs has had main effect on other arts thus they can be a rich source for modern art.

\section{References}

[1] Ansari, Jamal (1365). History of Sassanid dynasty molding art and its effect on Islamic works. Art Journal, N (19).

[2] Bosali, Mariyo (1376). Iran art history (2). Parthian and Sassanid art. Translated by Dr Yaghoub Ajand.

[3] Sami Ali (1355). Sassanid architecture. Art and people magazine, 165-166. 
[4] San Artoor Cristian (1384). Iran in the Sassanid dynasty. Translated by Rashid Yasmi, publisher of Tehran temporary sound.

[5] Khazai Mohammad (1381). Designs of molding and carving on stone. Islamic art studies institution.

[6] Behnam Isa. Sassanid designs. Speech Magazine, month Day of 1332-1333.

[7] Pup Artoor, Baltroshites, Yourgise (1384). Recorded designs. Translated by Jilbert Seddigh pour, Mirdashti publisher.

[8] Pup, Artoor, Ackerman, Fillips (1387). A searching in Iran art from period before the history until today, second volume. Sassanid dynasty. Scientific- culture publisher.

[9] Pup, Artoor, Ackerman, Fillips (1387). A searching in Iran art from period before the history until today, seventh volume. Sassanid dynasty. Pictorial, Scientific- culture publisher.

[10] Namjo, Abbas, Frozani, Seyed Mehdi (1392). Semiotics and comparative study of Sassanid and Safavid textiles designs elements. Art, science and culture Journal, winter. 